\title{
AN EMERGING BUT VULNERABLE MIDDLE CLASS: A DESCRIPTION OF TRENDS IN ASIA AND THE PACIFIC
}

\author{
Orlando Zambrano Roman*
}

The objective of the present paper is to examine the extent to which economic growth and public social expenditure in Asia and the Pacific have translated into an increasing middle class. Using international poverty lines and an absolute definition of the middle class, it is estimated that between 1999 and 2015, 1.2 billion people moved into the Asia-Pacific middle class and that the share tripled, from 13 to 39 per cent of the total population. This expansion, however, did not translate into an income-secure middle class, as almost one billion people are vulnerable and at risk of falling back into poverty. Examination at the country-level reveals that large disparities persist in the region, as most countries need to sustain economic growth and at the same time guarantee that the gains are sufficiently distributed to increase the size of the middle class.

JEL classification: D31, I32, 015

Keywords: poverty, middle class, vulnerability, Asia and the Pacific

Orlando Zambrano Roman, PhD candidate, Department of International Economics, The Graduate Institute, Geneva (IHEID) (email: orlando.zambranoroman@graduateinstitute.ch). The research for this paper was conducted at the Social Development Division of the Economic and Social Commission for Asia and the Pacific (ESCAP). I am particularly grateful to Ermina Sokou for her guidance and invaluable comments on the underlying framework and findings. Advice given by Patrik Andersson was also instrumental in enhancing the scope of the analysis. 


\section{INTRODUCTION}

In recent decades, development in Asia and the Pacific often has been viewed as a success story. Economic growth has generated new jobs, increased incomes, improved access to basic services and opportunities, and led to advances in poverty reduction (ESCAP, 2019). Between 1999 and 2015, moderate poverty in the region, defined as living below $\$ 3.20$ per day, fell from 66 to 27 per cent, while gross domestic product (GDP) per capita more than doubled. This surge translated into an increasing proportion of the population moving to higher incomes within their country's income distribution, thus forming an emerging middle class.

The middle class is often perceived as the engine of economic growth. Individuals in this stratum have consumption patterns above subsistence levels, allowing them to invest in productive activities and accumulate physical and human capital (Pezzini, 2012). Growing disposable incomes result in higher spending on leisure, entertainment and a range of basic services, such as health and education, and consumer goods, such as washing machines, telephones and computers (Kharas and Hamel, 2018a). As this group expands, so does its weight and voice in such matters as social protection and the public provision of services, which can shape institutions and promote good governance (Birdsall, 2015; Desai and Kharas, 2017).

The size of the middle class is not only instrumental in assessing the economic health of a country, but it also serves as a platform to estimate standards of living and the redistribution of economic growth. For this paper, international poverty lines and an absolute definition of the middle class are used to assess the size and growth of the Asia-Pacific middle class. The analysis sheds light on the extent to which economic growth and public social expenditure have translated into higher standards of living between 1999 and 2015. It also shows how distributional changes have come alongside growing income inequalities in selected countries.

This paper is structured as follows: in section II, an overview of the existing literature is given along with a definition of the concept of vulnerability and the middle class. Section III includes a description of the data used and provides the framework to assess middle-class changes over time. Section IV contains a discussion on regional trends, while focusing on the performance of the two most populous countries: China and India. In section V, the composition of the Asia-Pacific middle class is further explored by analysing the most and least successful countries in the region in terms of their income distribution. Section VI concludes with some remarks on the middleclass expansion. 


\section{POVERTY, VULNERABILITY AND THE MIDDLE CLASS}

The concept of the middle class is often weighted with social, political and historical implications. However, much of the recent academic and political discourse concerns the income dimension, as it refers to a stratum of the income distribution rather than an analysis of class. Individuals belonging to the middle class are expected to have a reasonable amount of disposable income to cover subsistence expenditures and enable them to buy consumer durables, invest in productive activities and save for the future (Kharas and Hamel, 2018b).

In the context of the 2030 Agenda for Sustainable Development, this notion carries great weight, as the pledge of leaving no one behind is also a call to end extreme poverty, curb inequalities and raise the well-being of all. Middle-class expansion underlies the commitment to "by 2030, reduce at least by half the proportion of men, women and children of all ages living in poverty in all its dimensions according to regional definitions" (Sustainable Development Goal 1, target 1.2), "empower and promote the social, economic, and political inclusion of all irrespective of age, sex, disability, race, ethnicity, origin, religion or economic or other status" (Sustainable Development Goal 10, target 10.2), and embodies other dimensions of sustainable development, such as equal access to services and opportunities.

A large amount of literature underscores the relationship between middle-class expansion, social gains and economic growth. Dabla-Norris and others (2015) find that after controlling for several covariates, a percentage point increase in the income share of the middle class is associated with a 0.38 percentage point rise in economic growth. Razafimandimby (2017) finds that a large and wealthy middle class positively affects growth and development, while Desai and Kharas (2017) show a negative and significant relationship between middle-class expansion and extreme poverty. ${ }^{1}$ Chun, Hasan and Ulubasoglu (2011) argue that the middle class affects economic growth through higher human capital investment, while Easterly (2001) and Loayza, Rigolini and Llorente (2012) underscore that countries where the middle class is a high proportion of the population have greater physical and human capital, less political instability and stronger institutions. Ravallion (2001) and Fosu (2017) argue that high inequality limits the effectiveness of growth in reducing poverty, thus curbing an expanding middle class, while Van de Walle (2011) shows a negative correlation between the size of the middle class and inequality.

However, Pezzini (2012), Birdsall, Lustig and Meyer (2014) and Kochhar (2015) emphasize that for the middle class to be the driver of this virtuous cycle, the risk

Desai and Kharas (2017) also find that this effect diminishes once the size of the middle class approaches 30 per cent of the population. 
of falling back into poverty needs to be eliminated. ${ }^{2}$ Individuals with incomes just above the poverty level would not be able to have a reasonable amount of disposable income or be able to cope with idiosyncratic risks, such as unemployment or illness. In addition, their capacity to accumulate human capital would also be restricted, as insufficient income would not allow for investments in proper health care and quality education, or enable consumption smoothing through savings.

For the middle class to enjoy economic security and boost economic growth, drive investments, sustain consumption, and foster quality public services and social protection systems, it needs to attain a reasonable standard of living that is sufficiently above the poverty level.

\section{DATA AND METHODOLOGY}

To some extent, the definition of the middle class is rather arbitrary and depends on the purpose of the analysis at hand. Some authors, such as Milanovic and Yitzhaki (2002), have defined the world's middle class as those countries with standards of living between the mean income level of Brazil and Italy. Kharas (2010) sets the global middle class as the households with per capita expenditure between $\$ 10.00$ and $\$ 100.00$ per day (2005 purchasing power parity (PPP)), while Kochhar (2015) adopts a threshold of between $\$ 10.00$ and $\$ 50.00$ per person per day (2011 PPP). Banerjee and Duflo (2008) define the middle class as households with daily per capita expenditure between \$2.00 and \$10.00 (2005 PPP), while Birdsall (2010) includes individuals with income levels at or above $\$ 10.00$ per day, and at or below the 95th percentile of the income distribution in their own country. Furthermore, Razafimandimby (2017) distinguishes four subgroups of the middle class by daily household per capita income: a floating class (\$2.00-\$4.00), a lower-middle class (\$4.00-\$10.00), an upper-middle class (\$10.00-\$20.00), and a higher-middle class (\$20.00-\$100.00) (2011 PPP). In Asia and the Pacific, Chun (2010) uses \$2.00 and $\$ 20.00$ per person per day as the lower and upper bounds of the middle class (2005 PPP).

For this paper, an absolute middle-class approach from the standpoint of developing countries in Asia and the Pacific is used to estimate the size and share of the middle class when compared to the developed world. ${ }^{3}$ Two data sources are used to assess changes and develop inequality estimates between 1999 and 2015:

\footnotetext{
In addition, the extent to which the middle class becomes larger and wealthier also plays a role in forming expectations of further growth (Birdsall, 2015).

3 The middle-class absolute approach, which is closely related to the notion of PPP, entails using a single metric to depict the same standards of living in Asia and the Pacific.
} 
population income distributions are obtained from the World Bank online poverty tool, PovcalNet, from which poverty measures are drawn from households' income or consumption expenditure levels, and expressed in 2011 PPP. ${ }^{4}$ Data are drawn from the World Inequality Database to estimate income changes across population percentiles in selected countries. Out of the 53 member States of the Economic and Social Commission for Asia and the Pacific (ESCAP), data are shown for 37 countries (annex table A.1). ${ }^{5}$

Following Ravallion (2010), the Asia-Pacific middle class is defined as the group of a population who are not poor by upper-middle income country standards $(\$ 5.50$ per person per day), but still poor by high income country standards $(\$ 21.70$ per person per day). The definition anchors the discussion of the Asia-Pacific middle class to the standards of living in the developing and developed world alike. Using international poverty lines, the region's population is divided into four income groups to estimate the poverty headcount at different income levels: poor ( $<\$ 3.20$ per day); near poor ( $\$ 3.20-\$ 5.50$ per day); middle class $(\$ 5.50-\$ 21.70$ per day); and "global middle class" ( $>\$ 21.70$ per day). ${ }^{6}$ Starting with the assumption that the middle class begins where poverty ends, the lower bound for defining the Asia-Pacific middle class is set at $\$ 5.50$ per person per day. This value corresponds to the poverty line of upper-middle income countries. As an upper bound, the poverty line of high income countries of \$21.70 per person per day is used (Jolliffe and Prydz, 2016). Households with per capita incomes beyond this threshold are not poor by any international standard; accordingly, they are considered to belong to the "global middle class".

In this paper, the $\$ 5.50-\$ 21.70$ bracket constitutes the Asia-Pacific middle class. The wide range, however, fails to capture individuals that could be trapped in vulnerable situations moving in and out of poverty at $\$ 5.50$ per day. On this basis, $\$ 10.00$ per day is used to disaggregate the middle class. Based on evidence presented by Lopez-Calva and Ortiz-Juarez (2011), this threshold has gained acceptance among academics because households living with a per capita income above this

4 Purchasing power parity, which is exchange rates adjusted for differences in the prices of goods and services across countries, allows for regional aggregates, cross-country, and over time comparisons.

5 France, the Netherlands, the United Kingdom of Great Britain and Northern Ireland, and the United States of America are ESCAP member States, but are located outside of Asia and the Pacific. Moreover, Australia, Japan, and the Republic of Korea are excluded from the analysis because they are high-income countries with absolute poverty lines that exceed $\$ 21.70$ per person per day.

6 At current 2019 dollar prices, the income levels correspond to the following: poor (<\$3.64 per day), near poor (\$3.64-\$6.25 per day), middle class $(\$ 6.25-\$ 24.67$ per day), and "global middle class" (> \$24.67 per day). 
level have a low probability of falling back into poverty. ${ }^{7}$ The same, or virtually the same threshold has been used by Birdsall (2010); Kharas (2010); Birdsall, Lustig and Meyer (2014); Jolliffe and Lanjouw (2014); Kochhar (2015); and Desai and Kharas (2017) as the cut-off income level between those considered to be vulnerable and those considered to be income-secure. ${ }^{8}$ The Asia-Pacific middle class is, therefore, divided into the vulnerable cohort $(\$ 5.50-\$ 10.00$ per day), and the income-secure cohort ( $\$ 10.00-\$ 21.70$ per day). Moreover, the poverty line of lower-middle income countries, defined as living below $\$ 3.20$ per day, is used to distinguish between the poor and those living just below $\$ 5.50$ per day with the potential to belong to the Asia-Pacific middle class (figure 1).

\section{Figure 1. Disaggregation of the Asia-Pacific middle class}

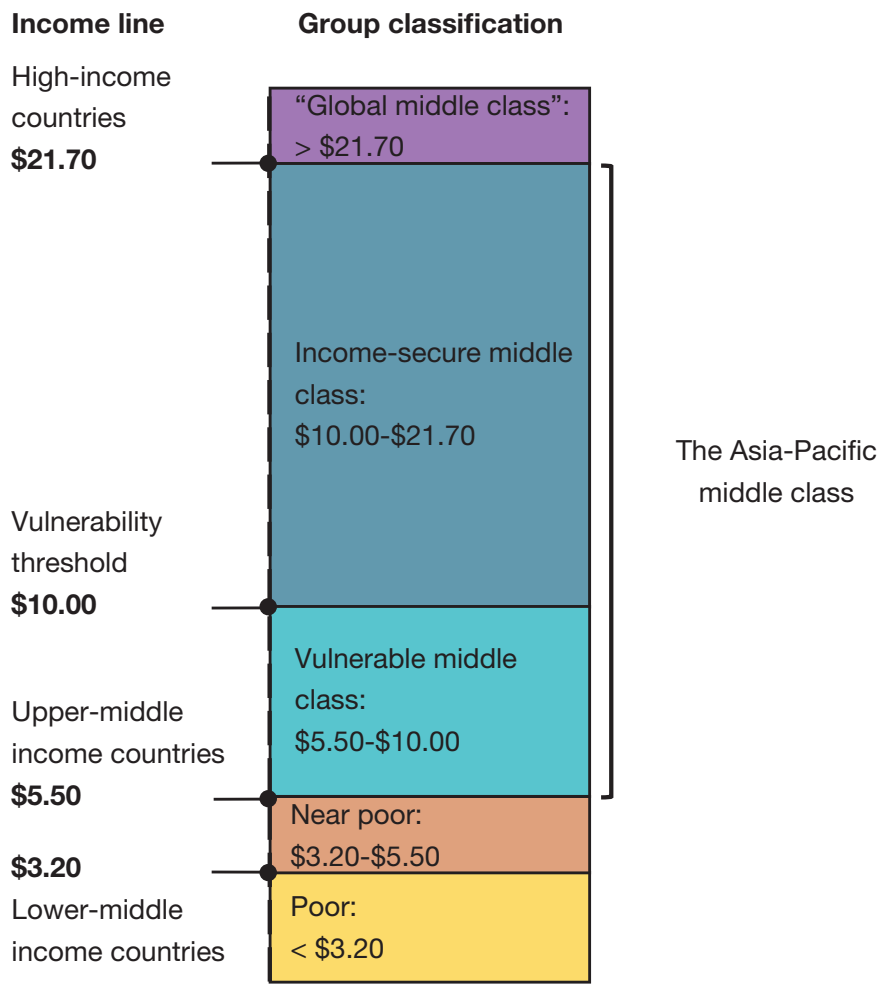

Source: Author's elaboration based on Lopez-Calva and Ortiz-Juarez (2011); and Jolliffe and Prydz (2016).

\footnotetext{
It is estimated that households in Chile, Mexico, and Peru have less than a 10 per cent probability of falling back into poverty if their income is at least $\$ 10.00$ per person per day (2005 PPP) (LopezCalva and Ortiz-Juarez, 2011).

8 The vulnerability threshold of $\$ 10.00$ per person per day is about three times the poverty line of lower-middle income countries (\$3.20 per person per day) as used in this paper.
} 


\section{THE GROWING MIDDLE CLASS IN CHINA AND INDIA}

The Asia-Pacific middle class has experienced steep growth in terms of size and share of the total population. Almost 1.2 billion people moved to the middle class, which increased in absolute size from 500 million in 1999 to 1.7 billion in 2015, while the percentage share tripled from 13 to 39 per cent of the total population (annex table A.2).

Authors, such as Drysdale and Armstrong (2010) and Huang and Wang (2011), attribute this expansion to the region's high annual GDP growth rate, which enabled many to escape poverty and improve their standards of living between 1999 and 2015. ${ }^{9}$ Alongside economic growth, many countries also made strides in alleviating poverty, thus allowing for an emerging middle class by fostering investments in human capital and creating the conditions for many to take advantage of growthrelated opportunities. ESCAP (2018) argues that if countries in the region were to further increase the amount of public social expenditure in education, health care, and social protection to match global averages, 328 million people would be lifted out of moderate poverty and 52 million out of extreme poverty by 2030 .

In analysing middle-class changes, estimates indicate that a dramatic shift occurred from 1999 to 2015. In 1999, two thirds of the population in Asia and the Pacific 2.3 billion people - were poor, with an income of less than $\$ 3.20$ per day while in 2015, the bulk of the population - 1.7 billion people - were considered middle class (figures 2 and 3). Yet, when disaggregating the Asia-Pacific middle class to consider the vulnerability threshold of $\$ 10.00$ per day, estimates show that almost 1 billion live at risk of falling into poverty. These figures point to movements out of poverty to incomes levels just above poverty.

China and India had an average annual GDP growth rate of 9.5 and 7.2 per cent, respectively (World Bank, 2019). 


\section{Figure 2. Share of the Asia-Pacific middle class, 1999-2015}

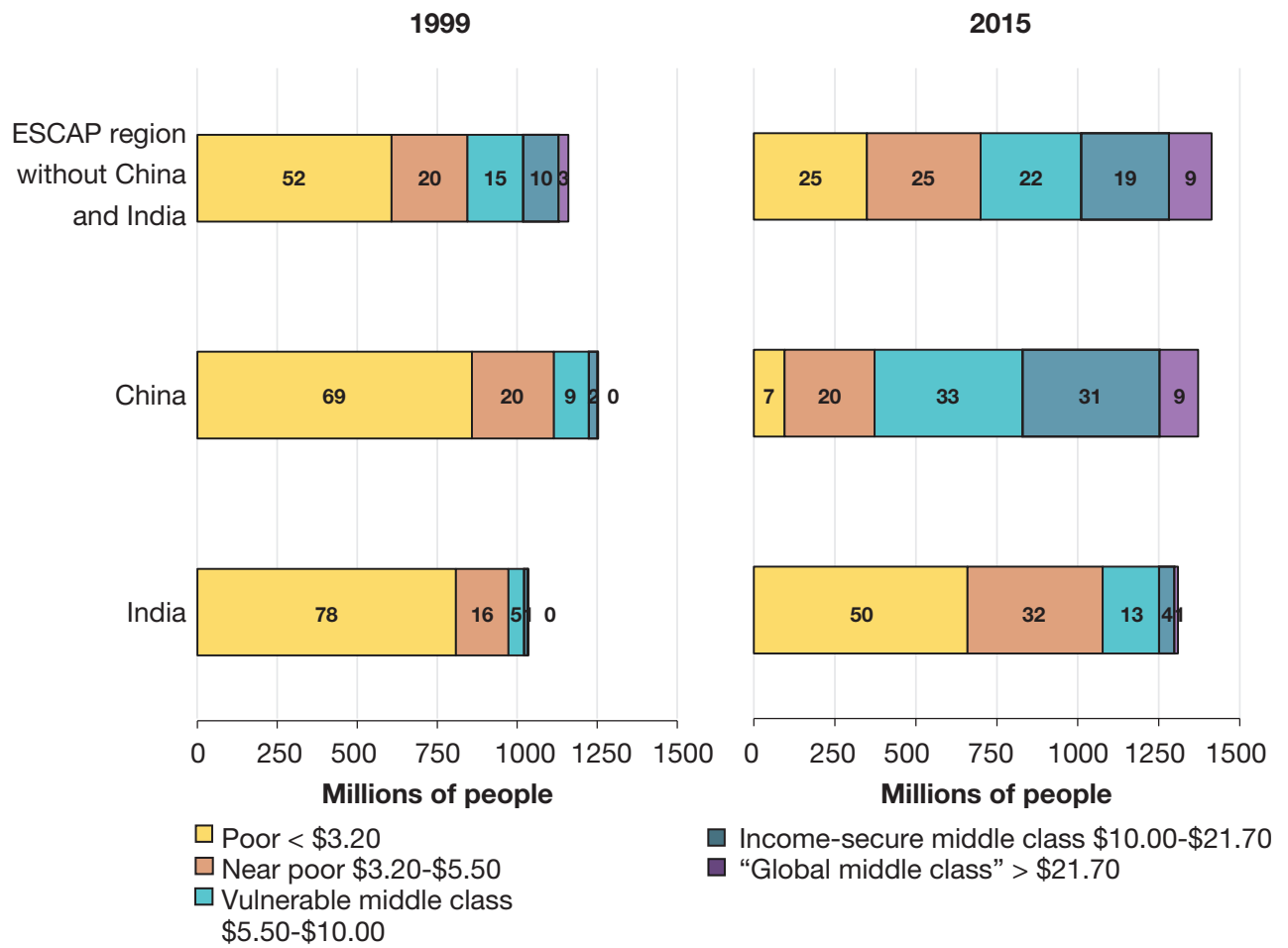

Source: Author's elaboration based on PovcalNet: the online tool for poverty measurement developed by the Development Research Group of the World Bank.

Note: $\quad$ The numbers inside the bars represent the share of the population belonging to each income group.

A closer look at trends reveals that the expansion of the middle class in the AsiaPacific region can be attributed to poverty reduction in the most populous countries: China and India. These best performers added 900 million people to the middle class between 1999 and 2015, comprising 75 per cent of the total advancement in the region (figure 3). 


\section{Figure 3. Size of the Asia-Pacific middle class, 1999-2015}

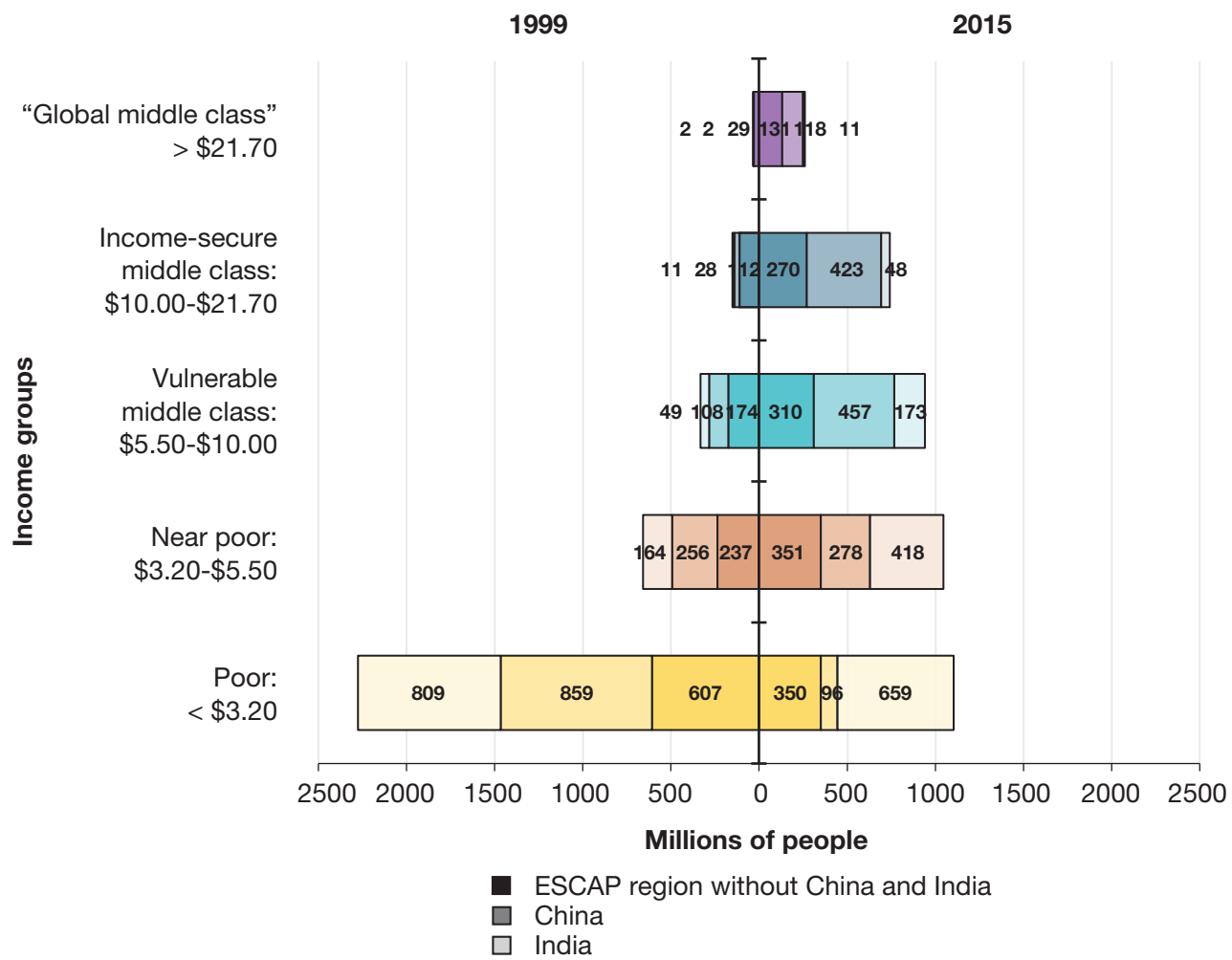

Source: Author's elaboration based on PovcalNet: the online tool for poverty measurement developed by the Development Research Group of the World Bank.

Note: The numbers inside the bars represent the size of the population in millions of people belonging to each income group.

In 1999, two thirds of the population of China - 859 million - lived below $\$ 3.20$ per day; sixteen year later, in 2015, two thirds of the population - 880 million - belonged to the middle class. Of those classified as middle class, 457 million were considered vulnerable and 423 million people were seen as being income-secure. By comparison, estimates in India suggest that in 1999, 78 per cent of the population - 809 million - lived below $\$ 3.20$ per day, and in 2015, half of the population - 659 million - were still living in poverty. Only 220 million people were considered middle class, with 79 per cent of this figure - 173 million - belonging to the vulnerable stratum. Notably, only 48 million people were considered income-secure. 
Distinct middle-class trends between China and India raise questions about the impact of growth and the nature of public social expenditure in reducing poverty and raising standards of living. China was able to sustainably reduce poverty and increase the size of its middle class, while in India, the spells of development did not trickle down to those most in need. Although both countries attained high GDP growth rates, investment in human capital differed between 1999 and 2015. In China, the total public social expenditure as a percentage of GDP increased from 4.7 to 6.3 per cent, as compared to a range of 1.6 to 2.7 per cent in India. The proportion of the population covered by at least one social protection scheme (Sustainable Development Goal 1, target 1.3) was 63.0 per cent in China, compared to 19.0 per cent in India. Furthermore, 96.9 per cent of the population of China had legal health coverage in 2010, as compared to 12.5 per cent of the population of India (ILO, 2017). In figure 4 , growth incidence curves are used to explore how economic growth and public social expenditure translated into annualized income growth rates for all percentiles of the populations of China and India between 1999 and the latest year available.

The growth incidence curve for China underscores that the annualized GDP growth rate of 9.5 per cent, coupled with slower population growth, major reforms to create job opportunities and improved access to social protection, led to income growth rates between 2.9 to 14.5 per cent for the whole population. After comparing over time distributional changes (figures 2 and 3) with percentile income growth rates (figure 4), the growth incidence curve suggests that most of those considered poor or near poor in 1999 were able to sustainably move into the Asia-Pacific middle class. The Chinese middle class, located between the 27 and the 91 percentile of the income distribution in 2015, had annualized income growth rates between 6.3 and 8.6 per cent, as seen on the red part of the curve.

The growth incidence curve also underlines growing income inequalities. A closer look at the income growth rate of the bottom 10 per cent when compared to the top 0.1 per cent shows that the standards of living of the poorest improved, but the gains of growth mostly benefited those that were already wealthy. Income growth was more rapid at the middle and higher segments of the income distribution when compared to the lower end. Xie and Zhou (2014); ILO (2017); and Jain-Chandra and others (2018) find that although for most of the population of China, incomes increased along with health and pension coverage through universal programmes, the urbanrural disparity also increased and gaps in access to tertiary education and financial services widened. In addition, Xie and Jin (2015) argue that inequality in China goes beyond the income sphere, as one third of the country's wealth is owned by the top 1 per cent of households, in contrast to the bottom 25 per cent who owns 1 per cent. 


\section{Figure 4. Growth incidence curves, China and India, 1999-latest}

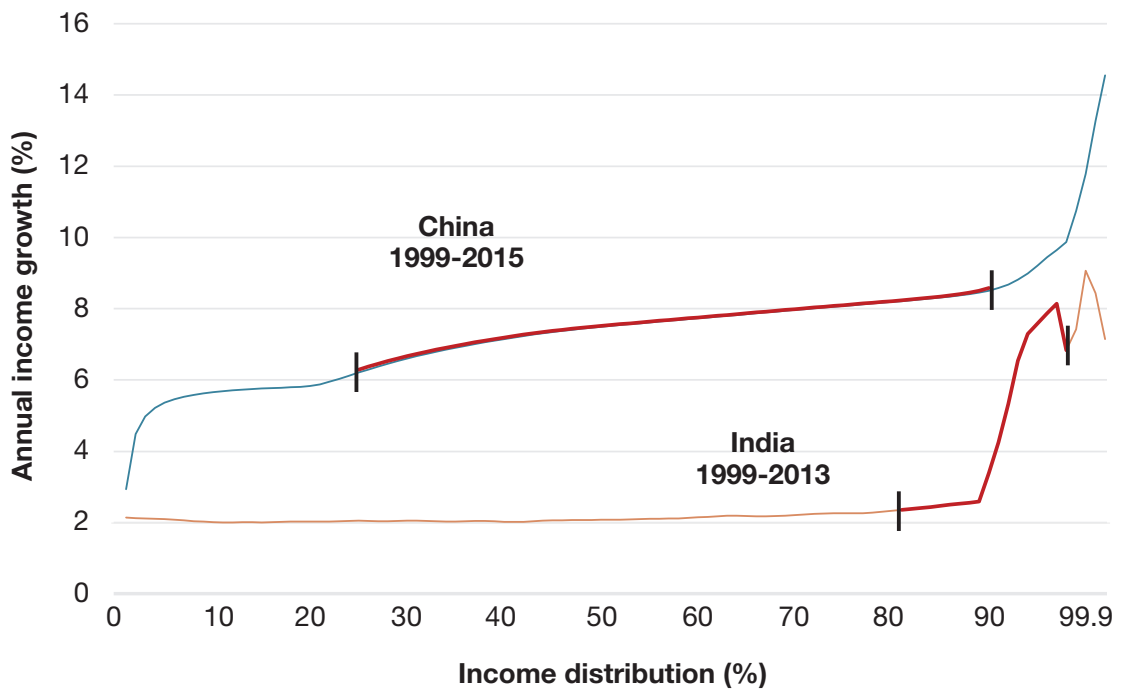

Source: Author's elaboration based on the World Inequality Database.

Note: Income refers to pre-tax national income. The variable is the sum of all pre-tax personal income flows accruing to the owners of the production factors, labour and capital, before considering the operation of the tax/transfer system, but after considering the operation of pension system. The red percentiles represent the annual growth rate of the cohort considered middle class at the latest available year.

The growth incidence curve in India is different. Although the country attained an average annual GDP growth rate of 7.2 per cent; rapid population growth low public expenditure on social protection and lack of job opportunities translated into slow growth in incomes of 90 per cent of the population. Figures 3 and 4 show this mismatch. The middle-class expansion in the country was the result of movements of people living just below $\$ 5.50$ per day into the vulnerable middle class. Only a few were able to attain high enough annualized income growth rates and move into the income-secure stratum. In addition, the middle class was squeezed between the 82 and the 99 percentile of the income distribution, suggesting that most of the population still lives on less than $\$ 5.50$ per day.

The growth income curve also highlights that the middle class will expand slowly as the gains of economic growth are concentrated at the top end of the income distribution. Given the current trend of GDP growth, an Indian living in poverty below $\$ 3.20$ per day in 2013 would move into the vulnerable middle class by at least 2041 , in almost a 30-year span, and into the income-secure middle class by at least 2071 . 
Chaudhuri and Kotwal (2013) and ILO (2018) note that economic growth in India was driven by the formal and skill-intensive sector, which created few opportunities for the vast majority working in low-skilled and informal markets. This skilled-biased growth also translated into growing income inequality between the rich and the rest of the population. While the top 0.1 attained income growth rates of 9 per cent, those below the 90 percentile enjoyed increases of 2.1 per cent. Credit Suisse (2018) argues that income inequality came alongside high wealth inequality, as the country's top 1 per cent held more than 50 per cent of the wealth in 2016.

\section{A CLOSER LOOK AT THE MIDDLE CLASS: THE VULNERABLE AND INCOME-SECURE STRATUM}

Between 1999 and 2015, China and India were leading middle-class expansion in Asia and the Pacific because of their size. In both countries, economic growth also came alongside growing income inequality. Other less populous countries had also made major strides in poverty reduction by fostering inclusive growth and investing in human capital. In this section, the composition of the Asia-Pacific middle class in the rest of countries for which data were available is reviewed.

Out of 37 countries considered, the size of their middle class increased between 1999 and 2015 in 34 countries (figure 5). Only the Federated States of Micronesia, Solomon Islands, and Vanuatu had a lower-middle-class share when compared to their 1999 value. Estimates also reveal that big disparities persisted in the region.

Mongolia and Viet Nam stand out in terms of middle-class expansion. Poverty fell from 86.0 to 19.8 per cent of the population in Mongolia, while the middle class expanded from 13.9 to 74.9 per cent. In Viet Nam, poverty fell from 86.8 to 30.9 per cent of the population while the middle class increased from 12.9 to 64.9 per cent. However, when disaggregating the middle class to consider the vulnerability threshold, estimates show the expansion was mainly because of movements out of poverty into the vulnerable middle class. This pattern is consistent throughout Asia and the Pacific. In only Azerbaijan, the Islamic Republic of Iran, Malaysia, the Russian Federation, Thailand and Turkey, the income-secure middle class comprised a greater share of the middle class in 2015.

Some countries, such as Bangladesh, India, the Lao People's Democratic Republic, Pakistan, Papua New Guinea, Solomon Islands, Timor-Leste, and Uzbekistan, still face several challenges as most of the population lives under $\$ 5.50$ per day. In addition, the share of the middle class is below 25 per cent of the population. These countries are in the most need to achieve sustained economic growth and receive assistance in developing policies to boost their middle class. 


\section{Figure 5. Share of the Asia-Pacific middle class, 1999-2015}

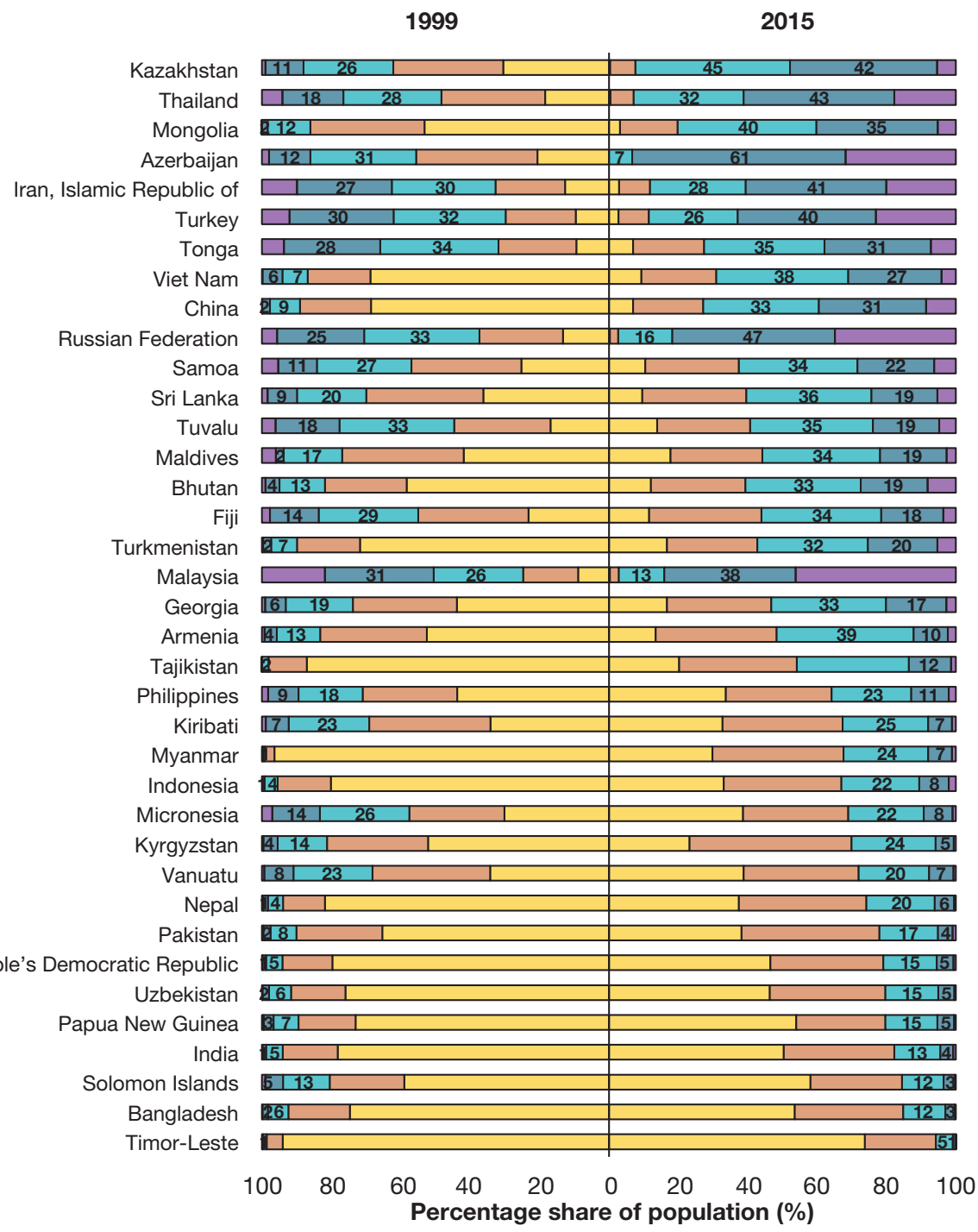

$\square$ Poor $<\$ 3.20$

$\square$ Near poor $\$ 3.20-\$ 5.50$

$\square$ Vulnerable middle class $\$ 5.50-\$ 10.00$

$\square$ Income-secure middle class $\$ 10.00-\$ 21.70$

$\square$ "Global middle class" > $\$ 21.70$

Source: Author's elaboration based on PovcalNet, the online tool for poverty measurement developed by the Development Research Group of the World Bank.

Note: The numbers inside the bars represent the share of the population belonging to the vulnerable and incomesecure middle class. 


\section{CONCLUDING REMARKS}

The present paper entails a review of the extent to which economic growth and public social expenditure in Asia and the Pacific has translated into an increasing middle class. After dividing the region's population into four income groups: poor ( $<\$ 3.20$ per day); near poor $(\$ 3.20-\$ 5.50$ per day); middle class $(\$ 5.50-\$ 21.70$ per day); and "global middle class" ( $>21.70$ per day), estimates reveal that 1.2 billion people had moved into the Asia-Pacific middle class, while the share of middle class tripled from 13 to 39 per cent of the total population.

Analysis at the country level indicates that large disparities persist in the region. China, Mongolia and Viet Nam have experienced the greatest middle-class expansion. On the contrary, Bangladesh, India, the Lao People's Democratic Republic, Pakistan, Papua New Guinea, Solomon Islands, Timor-Leste, and Uzbekistan still face several challenges in boosting the size of their middle class. Results in China and India underscore that economic growth rose in tandem with income inequality, as the gains were concentrated among the top 0.1 per cent of the income distribution. Furthermore, only in Azerbaijan, the Islamic Republic of Iran, Malaysia, the Russian Federation, Thailand and Turkey, most individuals moved into the income-secure middle class.

Altogether, estimates suggest that success in alleviating poverty in Asia and the Pacific has resulted in an emerging but vulnerable middle class. Economic growth has translated into almost one billion people living just above $\$ 5.50$ per day and at risk of falling back into poverty. Accordingly, whether middle-class expansion is a cause for optimism relies upon each country's ability to sustain economic growth while guaranteeing that the gains are sufficiently shared. Political will, therefore, is paramount in creating the conditions for individuals to seize growth-related opportunities and guarantee that those in vulnerable situations are able to attain a higher standard of living.

The paper sets the stage for further policy discussions on the factors supporting middle-class expansion and the barriers curbing its growth. As large disparities persist in the region, emphasis should be directed towards the countries that are most in need of sustained economic growth and have greater potential to unlock the middle-class virtuous cycle. Only by removing persistent vulnerabilities can the middle class fulfil its role in driving investments, sustaining consumption, fostering quality public services and social protection systems, and boosting further economic growth. 


\section{Annex}

Table A.1 Data availability for countries in Asia and the Pacific

\begin{tabular}{|c|c|}
\hline Subregion & Country \\
\hline East and North-East Asia (ENEA) & $\begin{array}{l}\text { China } \\
\text { Mongolia }\end{array}$ \\
\hline South-East Asia (SEA) & $\begin{array}{l}\text { Indonesia } \\
\text { Lao People's Democratic Republic } \\
\text { Malaysia } \\
\text { Myanmar } \\
\text { Philippines } \\
\text { Thailand } \\
\text { Timor-Leste } \\
\text { Viet Nam }\end{array}$ \\
\hline South and South-West Asia (SSWA) & $\begin{array}{l}\text { Bangladesh } \\
\text { Bhutan } \\
\text { India } \\
\text { Iran, Islamic Republic of } \\
\text { Maldives } \\
\text { Nepal } \\
\text { Pakistan } \\
\text { Sri Lanka } \\
\text { Turkey }\end{array}$ \\
\hline North and Central Asia (NCA) & $\begin{array}{l}\text { Armenia } \\
\text { Azerbaijan } \\
\text { Georgia } \\
\text { Kazakhstan } \\
\text { Kyrgyzstan } \\
\text { Russian Federation } \\
\text { Tajikistan } \\
\text { Turkmenistan } \\
\text { Uzbekistan }\end{array}$ \\
\hline Pacific & $\begin{array}{l}\text { Fiji } \\
\text { Kiribati } \\
\text { Micronesia, Federated States of } \\
\text { Papua New Guinea } \\
\text { Samoa } \\
\text { Solomon Islands } \\
\text { Tonga } \\
\text { Tuvalu } \\
\text { Vanuatu }\end{array}$ \\
\hline
\end{tabular}


Table A.2 Size and percentage share of the Asia-Pacific middle class, 1999-2015

\begin{tabular}{|c|c|c|c|c|c|c|}
\hline \multirow{3}{*}{$\begin{array}{l}\text { Subregion } \\
\\
\begin{array}{l}\text { East and North-East Asia } \\
\text { (ENEA) }\end{array}\end{array}$} & \multicolumn{2}{|c|}{$\begin{array}{c}\text { People living between } \\
\$ 5.50-\$ 21.70 \text { per day } \\
\text { (millions) }\end{array}$} & \multicolumn{2}{|c|}{$\begin{array}{l}\text { Percentage share of } \\
\text { population }(\%)\end{array}$} & \multirow{2}{*}{$\begin{array}{c}\begin{array}{c}\text { Absolute } \\
\text { change in } \\
\text { number } \\
\text { of people }\end{array} \\
1999\end{array}$} & \multirow{3}{*}{$\begin{array}{c}\begin{array}{c}\text { Percent- } \\
\text { age point } \\
\text { change }\end{array} \\
2015 \\
47.261\end{array}$} \\
\hline & \multirow{2}{*}{$\begin{array}{c}1999 \\
136.380\end{array}$} & \multirow{2}{*}{\begin{tabular}{|c|}
2015 \\
881.870
\end{tabular}} & \multirow{2}{*}{$\begin{array}{l}1999 \\
9.548\end{array}$} & \multirow{2}{*}{$\begin{array}{r}2015 \\
56.81\end{array}$} & & \\
\hline & & & & & 745.490 & \\
\hline China & 136.048 & 879.638 & 10.86 & 64.15 & 743.590 & 53.29 \\
\hline Mongolia & 0.332 & 2.232 & 13.95 & 74.90 & 1.900 & 60.95 \\
\hline South-East Asia (SEA) & 79.780 & 258.045 & 16.015 & 42.21 & 178.265 & 26.200 \\
\hline Indonesia & 9.304 & 79.746 & 4.46 & 30.89 & 70.442 & 26.43 \\
\hline $\begin{array}{l}\text { Lao People's Democratic } \\
\text { Republic }\end{array}$ & 0.302 & 1.341 & 5.76 & 20.14 & 1.040 & 14.38 \\
\hline Malaysia & 12.941 & 15.652 & 57.11 & 50.95 & 2.711 & -6.16 \\
\hline Myanmar & 0.337 & 16.365 & 0.74 & 31.23 & 16.028 & 30.49 \\
\hline Philippines & 20.764 & 34.310 & 27.20 & 33.73 & 13.546 & 6.53 \\
\hline Thailand & 28.538 & 51.591 & 45.80 & 75.14 & 23.053 & 29.34 \\
\hline Timor-Leste & 0.071 & 0.070 & 1.42 & 5.68 & -0.001 & 4.26 \\
\hline Viet Nam & 7.522 & 58.970 & 9.82 & 64.30 & 51.447 & 54.48 \\
\hline $\begin{array}{l}\text { South and South-West Asia } \\
\text { (SSWA) }\end{array}$ & 165.249 & 409.874 & 11.249 & 21.94 & 244.625 & 10.692 \\
\hline Bangladesh & 9.677 & 23.809 & 7.50 & 14.77 & 14.132 & 7.27 \\
\hline Bhutan & 0.096 & 0.415 & 17.16 & 52.50 & 0.319 & 35.34 \\
\hline India & 59.796 & 221.491 & 5.78 & 16.92 & 161.695 & 11.14 \\
\hline Iran, Islamic Republic of & 37.214 & 54.020 & 57.20 & 68.07 & 16.806 & 10.87 \\
\hline Maldives & 0.053 & 0.223 & 19.05 & 54.38 & 0.170 & 35.34 \\
\hline Nepal & 1.354 & 7.257 & 5.81 & 25.32 & 5.902 & 19.51 \\
\hline Pakistan & 12.932 & 39.902 & 9.55 & 21.07 & 26.971 & 11.52 \\
\hline Sri Lanka & 5.319 & 11.552 & 28.70 & 55.09 & 6.234 & 26.39 \\
\hline Turkey & 38.807 & 51.204 & 62.30 & 65.42 & 12.398 & 3.12 \\
\hline North and Central Asia (NCA) & 99.718 & 129.702 & 45.871 & 56.56 & 29.984 & 10.691 \\
\hline Armenia & 0.496 & 1.439 & 16.04 & 49.29 & 0.944 & 33.25 \\
\hline Azerbaijan & 3.384 & 6.580 & 42.40 & 68.19 & 3.197 & 25.79 \\
\hline Georgia & 1.122 & 1.877 & 25.22 & 50.46 & 0.755 & 25.24 \\
\hline Kazakhstan & 5.488 & 15.248 & 36.76 & 86.93 & 9.759 & 50.17 \\
\hline Kyrgyzstan & 0.886 & 1.755 & 18.30 & 29.45 & 0.870 & 11.15 \\
\hline Russian Federation & 85.809 & 89.904 & 58.29 & 62.39 & 4.095 & 4.10 \\
\hline Tajikistan & 0.112 & 3.795 & 1.83 & 44.39 & 3.684 & 42.56 \\
\hline Turkmenistan & 0.436 & 2.894 & 9.75 & 51.95 & 2.458 & 42.20 \\
\hline Uzbekistan & 1.986 & 6.210 & 8.17 & 19.84 & 4.224 & 11.67 \\
\hline
\end{tabular}


Table A.2. (continued)

\begin{tabular}{|c|c|c|c|c|c|c|}
\hline \multirow{3}{*}{$\begin{array}{ll}\text { Subregion } \\
\text { Pacific }\end{array}$} & \multicolumn{2}{|c|}{$\begin{array}{l}\text { People living between } \\
\$ 5.50-\$ 21.70 \text { per day } \\
\text { (millions) }\end{array}$} & \multicolumn{2}{|c|}{$\begin{array}{l}\text { Percentage share of } \\
\text { population (\%) }\end{array}$} & \multirow{3}{*}{$\begin{array}{c}\begin{array}{c}\text { Absolute } \\
\text { change in } \\
\text { number } \\
\text { of people }\end{array} \\
1999 \\
1217\end{array}$} & \multirow{3}{*}{$\begin{array}{c}\begin{array}{c}\text { Percent- } \\
\text { age point } \\
\text { change }\end{array} \\
2015 \\
2.520\end{array}$} \\
\hline & \multirow{2}{*}{$\begin{array}{l}1999 \\
1.220\end{array}$} & \multirow{2}{*}{$\begin{array}{l}2015 \\
2.437\end{array}$} & \multirow{2}{*}{$\begin{array}{l}1999 \\
4.654\end{array}$} & \multirow{2}{*}{$\begin{aligned} 2015 \\
7.17\end{aligned}$} & & \\
\hline & & & & & & \\
\hline Fiji & 0.346 & 0.466 & 42.69 & 52.36 & 0.120 & 9.67 \\
\hline Kiribati & 0.024 & 0.035 & 29.83 & 31.47 & 0.011 & 1.64 \\
\hline $\begin{array}{l}\text { Micronesia, Federated } \\
\text { States of }\end{array}$ & 0.043 & 0.030 & 39.48 & 30.04 & -0.013 & -9.44 \\
\hline Papua New Guinea & 0.545 & 1.562 & 10.04 & 19.72 & 1.017 & 9.68 \\
\hline Samoa & 0.065 & 0.107 & 38.33 & 56.28 & 0.042 & 17.95 \\
\hline Solomon Island & 0.074 & 0.089 & 18.46 & 15.15 & 0.016 & -3.31 \\
\hline Tonga & 0.062 & 0.072 & 61.80 & 65.35 & 0.010 & 3.55 \\
\hline Tuvalu & 0.005 & 0.005 & 51.52 & 54.46 & 0.000 & 2.94 \\
\hline Vanuatu & 0.056 & 0.071 & 31.15 & 27.29 & 0.015 & -3.86 \\
\hline Total & 482.346 & 1681.928 & 13.25 & 39.16 & 1199.582 & 25.91 \\
\hline
\end{tabular}

Source: Author's elaboration based on PovcalNet: the online tool for poverty measurement developed by the Development Research Group of the World Bank. 


\section{REFERENCES}

Banerjee, Abhijit, and Esther Duflo (2008). What is middle class about the middle classes around the world? Journal of Economic Perspectives, vol. 22, No. 2, pp. 3-28.

Birdsall, Nancy (2010). The (indispensable) middle class in developing countries. In Equity and Growth in a Globalizing World. Ravi Kanbur and Michael Spence, eds. Washington, D.C.: World Bank.

(2015). Does the rise of the middle class lock in good government in the developing world? The European Journal of Development Research, No.27, pp. 217-229.

Birdsall, Nancy, Nora Lustig, and Christian Meyer (2014). The strugglers: the new poor in Latin America? World Development, vol. 60, pp. 132-146.

Chaudhuri, Arka, and Ashok Kotwal (2013). Why is poverty declining so slowly in India? Live Mint, 26 February. Available at www.livemint.com/Opinion/reZSnhy0ZGod3xTB6Qxr5J/Whyis-poverty-declining-so-slowly-in-India.html.

Chun, Natalie (2010). Middle class size in the past, present, and future: a description of trends in Asia. ADB Economics Working Paper Series, No. 217. Manila: ADB.

Chun, Natalie, Rana Hasan, and Mehmet Ulubasoglu (2011). The role of the middle class in economic development: what do cross-country data show? ADB Economics Working Paper Series, No. 245. Manila: ADB.

Credit Suisse (2018). Global Wealth Report 2018. Zurich: Credit Suisse Research Institute.

Dabla-Norris, Era, and others (2015). Causes and consequences of income inequality: a global perspective. IMF Staff Discussion Note. Available at www.imf.org/external/pubs/ft/ sdn/2015/sdn1513.pdf.

Desai, Raj, and Homi Kharas (2017). Is a growing middle class good for the poor? Social policy in a time of globalization. Global Economy and Development Working Paper, 105. Washington, D.C.: Brookings.

Drysdale, Peter, and Shiro Armstrong (2010). International and regional cooperation: Asia's role and responsibilities. Asian Economic Policy Review, vol. 5, No. 2, pp. 157-173.

Easterly, William (2001). The Middle Class Consensus and Economic Development. Washington, D.C.: World Bank.

Fosu, Augustin (2017). Growth, inequality, and poverty reduction in developing countries: recent global evidence. Research in Economics, vol. 71, No. 2, pp. 306-336.

Huang, Yiping, and Bijun Wang (2011). From the Asian miracle to an Asian century? Economic transformation in the 2000s and prospects for the 2010s. In Reserve Bank of Australia Annual Conference Volume. Reserve Bank of Australia.

International Labour Organization (ILO) (2017). World Social Protection Report 2017-19: Universal Social Protection to Achieve the Sustainable Development Goals. Geneva.

(2018). Women and Men in the Informal Economy: A Statistical Picture (Third Edition). Geneva.

Jain-Chandra, Sonali, and others (2018). Inequality in China - Trends, drivers and policy remedies. IMF Working Paper, 18/127. Washington, D.C.: IMF. 
Jolliffe, Dean, and Peter Lanjouw (2014). A measured approach to ending poverty and boosting shared prosperity: concepts, data, and the twin goals. Policy Research Report. Washington: D.C.: International Bank for Reconstruction/The World Bank Group.

Jolliffe, Dean, and Espen Prydz (2016). Estimating international poverty lines from comparable national thresholds. Policy Research Working Paper, No. WPS 7606. Washington, D.C.: World Bank.

Kharas, Homi (2010). The emerging middle class in developing countries. OECD Development Centre Working Papers, No. 285. Paris: OECD Publishing.

Kharas, Homi, and Kristofer Hamel (2018a). A global tipping point: half the world is now middle class or wealthier. Brookings, 27 September. Available at www.brookings.edu/blog/ future-development/2018/09/27/a-global-tipping-point-half-the-world-is-now-middleclass-or-wealthier/.

(2018b). Who will drive consumer spending in the next decade? OECD Development Matters, 7 November. Available at http://oecd-development-matters.org/2018/11/07/ who-will-drive-consumer-spending-in-the-next-decade/.

Kochhar, Rakesh (2015). A global middle class is more promise than reality: from 2001 to 2011 , nearly 700 million step out of poverty, but most only barely. Pew Research Center/Global Attitudes and Trends, 8 July. Available at www.pewresearch.org/global/2015/07/08/aglobal-middle-class-is-more-promise-than-reality/.

Loayza, Norman, Jamele Rigolini, and Gonzalo Llorente (2012). Do middle classes bring institutional reforms? Economic Letters, vol. 116, No. 3, pp. 440-444.

Lopez-Calva, Luis, and Eduardo Ortiz-Juarez (2011). A vulnerability approach to the definition of the middle class. The Journal of Economic Inequality, vol. 12, No. 1, pp. 23-47.

Milanovic, Branko, and Shlomo Yitzhak (2002). Decomposing world income distribution: Does the world have a middle class? Policy Research Working Paper, No. WPS 2562. Washington, D.C.: World Bank.

Pezzini, Mario (2012). An emerging middle class. OECD Observer. Available at http://oecdobserver. org/news/fullstory.php/aid/3681/An_emerging_middle_class.html.

Ravallion, Martin (2001). Growth, inequality and poverty: looking beyond averages. World Development, vol. 29, No. 11, pp. 1803-1815.

(2010). The developing world's bulging (but vulnerable) middle class. Washington, D.C.: World Bank.

Razafimandimby, Riana (2017). Middle-class composition and growth in middle-income countries. ADBI Working Paper, 753. Tokyo: Asian Development Bank Institute.

United Nations, Economic and Social Commission for Asia and the Pacific (ESCAP) (2018). Social Outlook for Asia and the Pacific: Poorly Protected. Sales No. E.19.II.F.2.

(2019). Closing the Gap: Empowerment and Inclusion in Asia and the Pacific. Sales No. E.19.II.F.8.

Van de Walle, Nicolas (2011). Democracy, the State and the African Middle Class". Mimeo. Ithaca, New York: Cornell University. 
World Bank (2019). GDP growth (annual \%). World Development Indicators. Available at http:// databank.worldbank.org/source/world-development-indicators.

Xie, Yu, and Yongai Jin (2015). Household wealth in China. Chinese Sociological Review, vol. 3, No. 47 , pp. 203-229.

Xie, Yu, and Xiang Zhou (2014). Income inequality in today's China. Proceedings of the National Academy of Sciences, vol. 111, No. 19, pp. 6928-6933. 